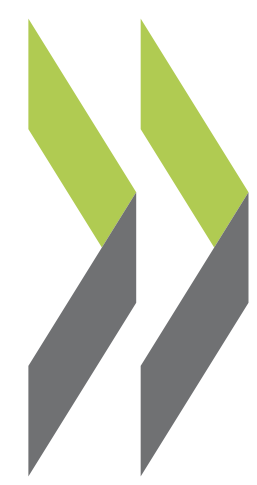

OECD Economics Department Working Papers No. 1112

\title{
New Evidence on the Determinants of Industrial Specialisation
}

Asa Johansson, Eduardo Olaberría 
Organisation de Coopération et de Développement Économiques

Organisation for Economic Co-operation and Development

18-Apr-2014

ECONOMICS DEPARTMENT

English - Or. English

\title{
NEW EVIDENCE ON THE DETERMINANTS OF INDUSTRIAL SPECIALISATION
}

\author{
ECONOMICS DEPARTMENTS WORKING PAPERS No. 1112
}

By Asa Johansson and Eduardo Olaberria

OECD Working Papers should not be reported as representing the official views of the OECD or of its member countries. The opinions expressed and arguments employed are those of the author(s).

Authorised for publication by Christian Kastrop, Director, Policy Studies Branch, Economics Department.

All Economics Department Working Papers are available through OECD internet website at www.oecd.org/eco/workingpapers

JT03356428

Complete document available on OLIS in its original format

This document and any map included herein are without prejudice to the status of or sovereignty over any territory, to the delimitation of international frontiers and boundaries and to the name of any territory, city or area. 
OECD Working Papers should not be reported as representing the official views of the OECD or of its member countries. The opinions expressed and arguments employed are those of the author(s).

Working Papers describe preliminary results or research in progress by the author(s) and are published to stimulate discussion on a broad range of issues on which the OECD works.

Comments on Working Papers are welcomed, and may be sent to OECD Economics Department, 2 rue André-Pascal, 75775 Paris Cedex 16, France, or by e-mail to eco.contact@oecd.org

This document and any map included herein are without prejudice to the status of or sovereignty over any territory, to the delimitation of international frontiers and boundaries and to the name of any territory, city or area.

\section{(C) OECD (2014)}

You can copy, download or print OECD content for your own use, and you can include excerpts from OECD publications, databases and multimedia products in your own documents, presentations, blogs, websites and teaching materials, provided that suitable acknowledgment of OECD as source and copyright owner is given. All requests for commercial use and translation rights should be submitted to rights@oecd.org 


\section{ABSTRACT/RÉSUMÉ \\ New Evidence on the Determinants of Industrial Specialisation}

Industrial specialization has important implications for economic performance; therefore, understanding its determinants is of key policy relevance. This paper quantifies the relationship between factor endowments, policies and institutions and patterns of industrial specialisation in production using a new cross-country dataset compiled by WIOD that includes 37 OECD and non-OECD countries and 26 sectors. An advantage of this database -as compared with those used by previous studies- is that makes it possible to look at industrial specialization in terms of value added instead of gross exports, covering both services and manufactures in a panel of advanced and developing economies. The empirical methodology is based on the idea that industries vary in the conditions that they need for production, and countries differ in their ability to provide for these industry-specific requirements. We find that not only cross-country differences in factor endowments, such as capital and labour, but also differences in investment in R\&D and policies or institutions, such as financial development, tariffs and taxes, and product and labour market regulation, can explain cross-country differences in industrial structure.

JEL classification codes: O57; C23.

Key words: intermediate input tariff, trade.

$* * * * * * * * * * * * * * * * * * * * * * * * * * * * * * * *$

\section{Nouveaux résultats sur les déterminants de la spécialisation industrielle}

La spécialisation industrielle a des implications importantes pour les performances économiques. Il est, par conséquent, essentiel d'en comprendre les déterminants. Ce papier quantifie la relation entre les dotations en facteurs, les politiques et institutions et les modèles de spécialisation industrielle dans la production en utilisant une nouvelle base de données internationales compilée par WIOD, qui comprend 37 pays membres et non membres de l'OCDE et 26 secteurs. Un avantage de cette base de données, par rapport à celles utilisées par les études précédentes, est qu'elle permet d'analyser la spécialisation industrielle en termes de valeur ajoutée et non par la valeur des exportations brutes, et aussi qu'elle comprend les services et les produits manufacturés pour un groupe de pays avancés et émergents. La méthodologie empirique est basée sur l'idée que les industries diffèrent dans les conditions requises pour la production, et les pays diffèrent dans leur capacité à répondre à ces exigences spécifiques de l'industrie. Nous constatons que non seulement les dotations en facteurs, comme le capital et le travail, mais aussi les politiques ou les institutions, comme le développement financier, les tarifs et taxes, les investissements en R \& D et la réglementation des marchés des produits et du travail, sont les principaux déterminants de la structure industrielle.

Classification JEL: O57; C23.

Mots clés: Droits de douane sur les biens intermédiaires, échanges 
TABLE OF CONTENTS

NEW EVIDENCE ON THE DETERMINANTS OF INDUSTRIAL SPECIALISATION ......................... 5

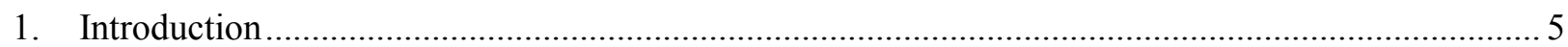

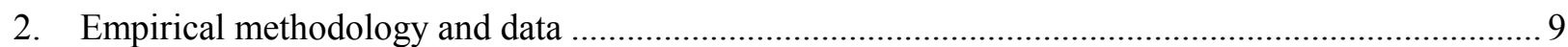

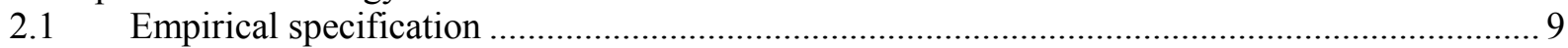

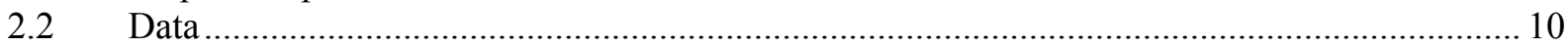

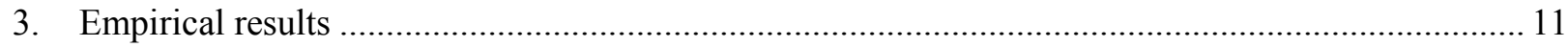

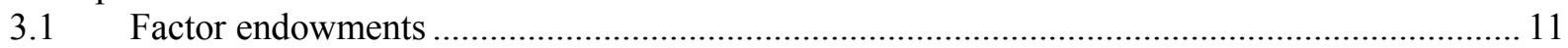

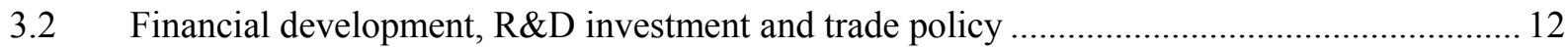

3.3 Product and labour market regulation and tax structure ....................................................... 15

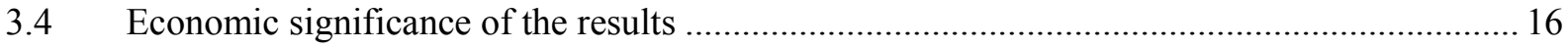

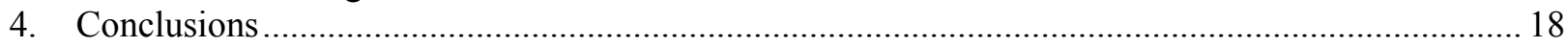

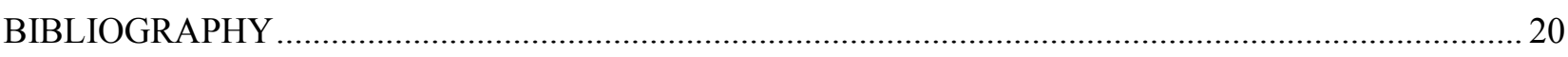

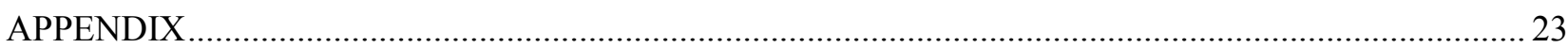

\section{Tables}

Table 1. Determinants of industrial specialisation: Factor endowments....................................... 12

Table 2. Determinants of industrial specialisation: Factor endowments and policies ....................... 14

Table 3. Determinants of industrial specialisation: Regulation and Tax Structure............................ 16

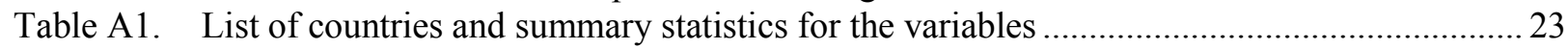

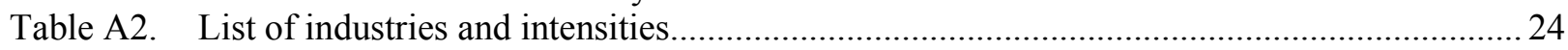

Table A3. Pairwise correlations between the dependant and explanatory variables ............................25

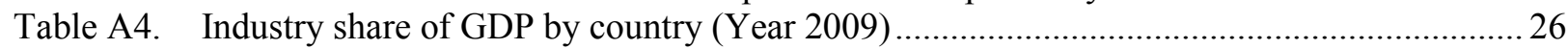

\section{Figures}

Figure 1. Services value added embodied in gross exports, 2009 ................................................. 6

Figure 2. Domestic and foreign content in gross exports of electronics .......................................... 7

Figure 3. Share of domestic value added in gross exports across countries 1995 and 2009, \%............ 7

Figure 4. Difference in industry share of GDP: actual and explained (predicted) by differences in

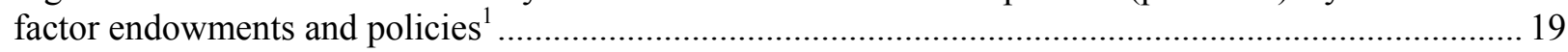


ECO/WKP(2014)8

\title{
NEW EVIDENCE ON THE DETERMINANTS OF INDUSTRIAL SPECIALISATION
}

\author{
By \\ Asa Johansson and Eduardo Olaberria ${ }^{1}$
}

\section{Introduction}

1. Industrial specialisation has important implications for economic performance. Both theory and evidence suggest that specialising in some industries can be more growth promoting than specialising in other industries. For example, in models with learning-by-doing externalities long run growth is endogenous and depends, among other things, on industrial specialisation (e.g. Matsuyama, 1992; Grossman and Helpman, 1991; Aghion and Howitt, 1998; Dalum et al., 1999; and Barro and Sala-i-Martin, 2003). On the empirical side, evidence suggests that countries that specialise in high value added industries, such as electronics, are more likely to grow faster (Amable, 2000 and Hausmann et al., 2007). Since industrial specialisation affects growth and has implications for wage inequality, understanding its determinants is of key policy relevance. The purpose of this paper is to explore this issue empirically to quantify the determinants of industrial specialisation. The general question asked in this paper is: Can international differences in factor endowments, policies and institutions explain international differences in industrial specialisation?

2. A driving force behind industrial specialisation is trade. Trade enables countries to specialise in a narrow range of goods in which the country is relatively more productive, leading to higher productivity growth and creating learning and scale effects. At the heart of conventional trade theory is the idea that international differences in production are determined by international differences in factor endowments. Various empirical approaches have been used to test the predictions of this theory, finding different results. The traditional approach to study specialisation assumes that all countries have access to the same technology (Harrigan, 1995; Davis and Weinstein, 1999; Reeve, 1998; Bernstein and Weinstein, 2002) and use cross-country data to estimate the association between factor endowments and the performance of a set of manufacturing industries. They find that increases in factor endowments, such as in the stock of capital per worker, have a positive and statistically significant impact on output in almost all manufacturing sectors. Other studies, such as Harrigan (1999) and Harrigan and Zakrajsek (2000), allow technology to differ across countries, and find that changes in factor endowments do not affect uniformly all industries. When factor endowments increase, GDP of some industries will increase while in some others it will decrease.

3. Recently, an increasing number of studies have also sought to quantify the role of policies and institutions for specialisation (e.g. Chor, 2010; Kowalski, 2011; Nunn and Trefler, 2013 and Johansson et al., 2013), showing that they can have an important impact. In particular, they find that differences in institutional quality, financial development and employment regulation explain differences in countries manufacturing exports.

4. Both the recent and the older literature relied on data for manufacturing industries only (e.g. Harrigan, 1995; Harrigan, 1997; Davis and Weinstein, 1999; Chor, 2010; Kowalski, 2011; Johansson et al., 2013). Yet services have, by far, the largest share in value added in most countries. Moreover, services

1 Asa Johansson is senior economist and Eduardo Olaberría is economist in the Policy Studies Branch. The authors would like to thank Giuseppe Nicoletti and Jean-Luc Schneider for their valuable comments and suggestions, Yassine Slaoui for his research assistance and Sarah Michelson for superb editorial assistance. 
contribute, on average, $45 \%$ of the value added in gross exports of manufacturing goods and in some countries this share is even higher (Figure 1).

5. $\quad$ Furthermore, Chor (2010), Kowalski (2011) and Johansson et al. (2013) look at trade patterns rather than production specialisation. However, the focus on the value of gross exports can be misleading because a large portion of this value is value added by a different sector or country (Figure 2). Indeed, the internationalisation of economic activity and the sourcing abroad of intermediate inputs have made the relationship between trade and value creation more complex. ${ }^{2}$ The domestic value added content of gross exports was significantly lower in 2009 than it was fifteen years earlier (Figure 3). Thus, there is a growing inability of gross exports to capture the value added by each sector and country, and therefore measures of specialisation based on gross exports can be misrepresentative (see Miroudot et al., 2009). A better measure of specialisation should be one based directly on the value added of each sector.

Figure 1. Services value added embodied in gross exports, 2009

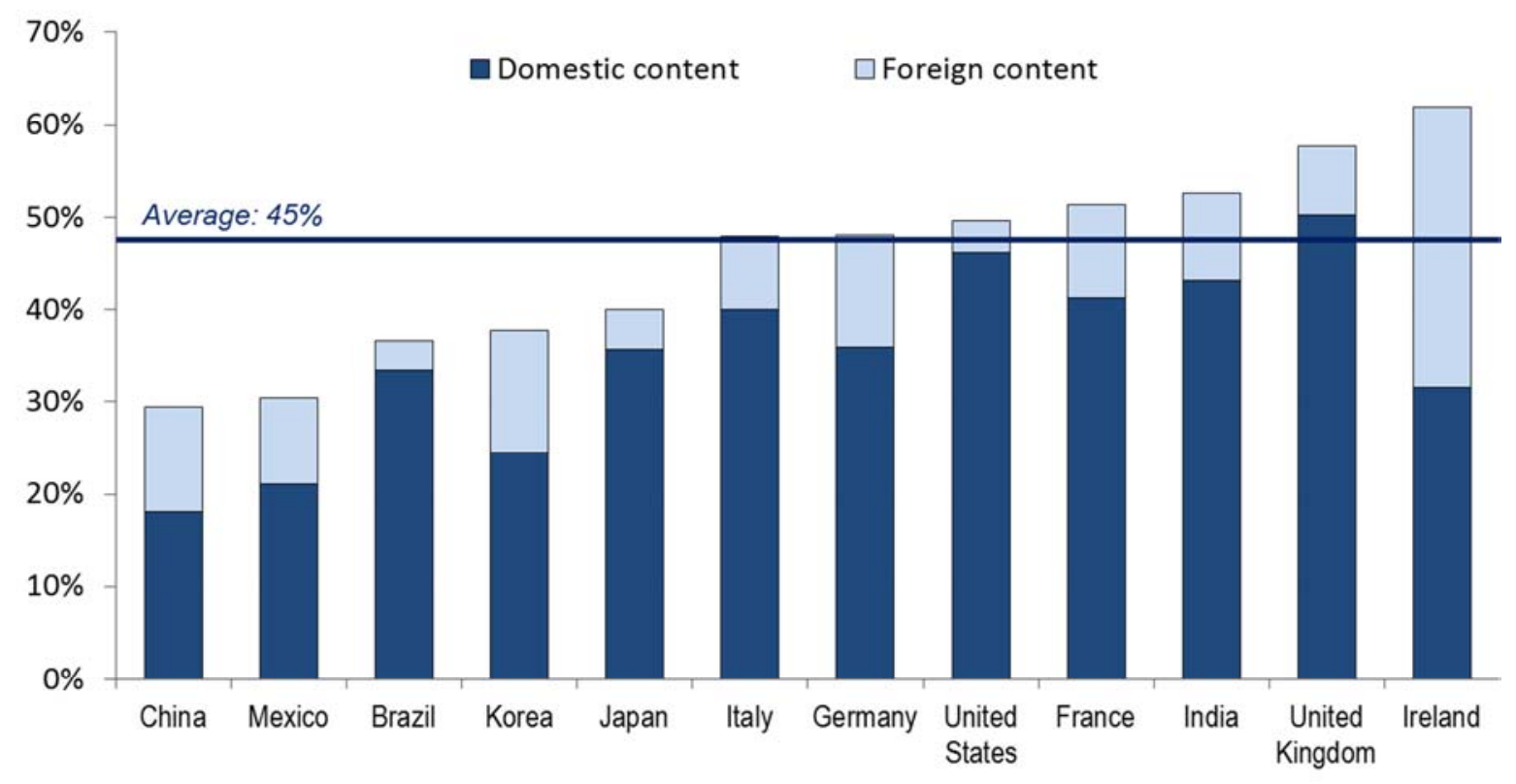

Source: OECD TiVA database.

2. For example, Koopman et al. (2010) found that, in China, the export sector consists largely of assembly activities based on imported intermediate goods and that the value added of these activities was much lower than suggested by gross exports. 
Figure 2. Domestic and foreign content in gross exports of electronics

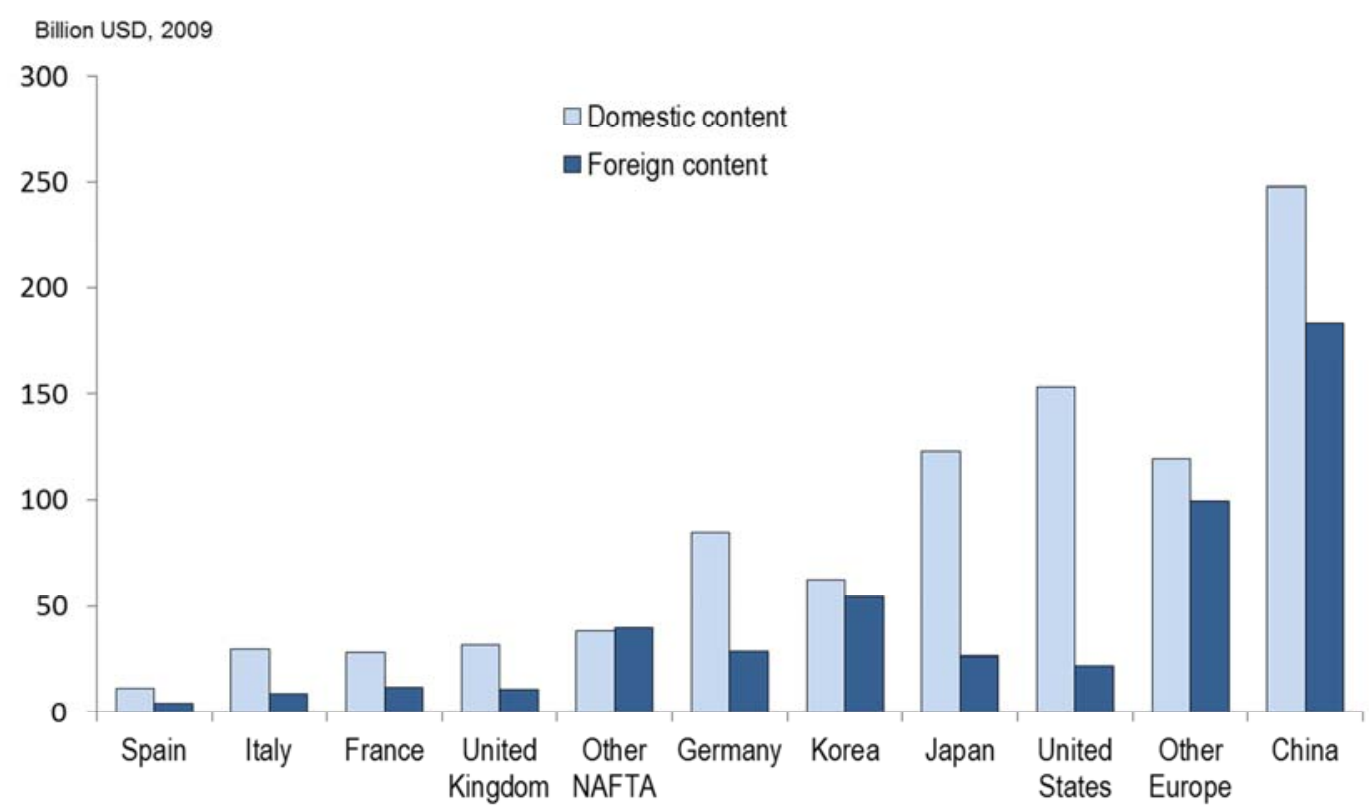

Source: OECD TiVA database.

Figure 3. Share of domestic value added in gross exports across countries 1995 and 2009, \%

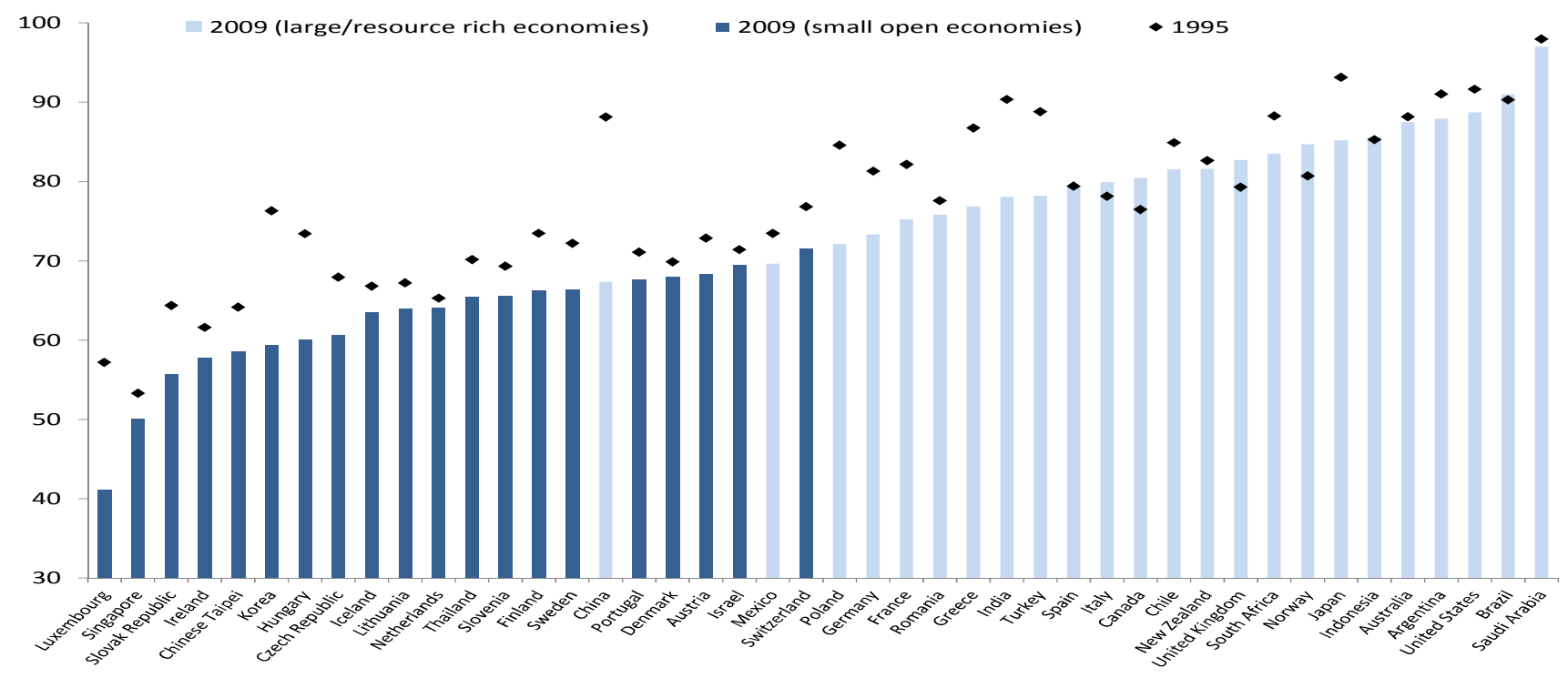

Source: OECD TiVA database.

6. This paper re-examines the findings of previous studies using a different and novel database that enables to measure specialisation on a value added basis and to include services and manufacturing industries. The paper also extends the analysis to some policies and institutions not considered before. The analysis is based on the recently issued World Input-Output Database (WIOD), which is constructed out of national supply- and use tables in combination with bilateral trade statistics as described in Timmer et al. 
(2012). This database distinguishes domestic value added for 37 industries and 40 emerging and developed countries. $^{3}$

7. The analysis covers the period 1995-2009 which allows to account for the significant change observed in the pattern of globalisation since the mid-1990s (Haskel et al., 2012), driven by three important factors: (1) the significant reduction in political barriers to trade ${ }^{4}$; (2) the decline in trade costs generated by the creation of the internet, which drove the cost of invoice and data to almost zero; and (3) the growth of GDP, and the corresponding share of world trade, of emerging countries accelerated in the mid-1990s, particularly in China, India, Russia and Brazil, thereby changing global specialisation patterns.

8. The empirical methodology follows Chor (2010) who specified a model in which the productivity of industries is driven by the interaction of country and industry characteristics. The intuition is simple: industries vary in the conditions needed for production and countries differ in their ability to provide for these conditions; hence, relative productivity across industries will be different in different countries. For example, industries that require a high share of highly skilled workers for production are likely to be relatively more productive and take a higher share of GDP in countries that are relatively well endowed with those workers. A similar argument applies for institutions and policies: e.g. in countries relatively more financially developed, industries that rely heavily on external financing are likely to grow faster and take a higher share of GDP than in countries with less developed financial markets.

9. Following this approach, this paper studies how capital per worker, the share of high skilled and low skilled workers, financial development, total R\&D spending (both private and public; from now on only R\&D spending), product and labour market regulation, and the structure of taxes and tariffs affect production specialisation. The three main findings are:

- Factor endowments, policies and institutions are critical determinants of industrial specialisation. The results confirm the findings of previous empirical studies: industries that are intensive in capital are larger (in terms of their value added over GDP) in countries that are relatively well endowed in capital; cross-country differences in education can significantly increase the value added share of industries intensive in human capital; industries that are relatively more dependent on external financing take up a larger share of GDP in countries with more developed financial markets (as measured by the ratio of credit to the private sector to GDP); relatively easier employment protection regulation and entry barriers can increase the share of GDP of industries facing high job turnover or high volatility of sales.

- Investment in $R \& D$ and tax structure can affect industrial specialisation. The results also suggest that industries that are highly dependent on innovation take up a higher share of GDP in countries that spend relatively more on research and development; and countries with higher labour taxes tend to specialise in industries that are less labour intensive. These findings are, to our knowledge, new in the empirical literature on the determinants of industrial specialisation.

- Trade policy can also affect industrial specialisation: tariffs on imported goods are likely to reduce value added in downstream industries, especially if these industries rely more on those protected intermediate goods.

3. Although WIOD has data for 40 countries, the explanatory variables are a limiting factor and at the end the sample includes 37 countries (see Table A1 in the appendix for a list of countries). Similarly, the analysis includes only 26 of the 37 industries to avoid sectors such as Public Administration or Health, that are likely to have different determinants than the ones considered in this paper.

4. At the multilateral level, after the 1994 Uruguay Round; several regional trade agreements were signed (e.g. NAFTA, Mercosur) and, in 2001, China accessed the World Trade Organization (WTO). 
10. The remainder of the paper proceeds as follows. Section 2 describes the empirical methodology and the data used. Section 3 discusses the results and section 4 offers concluding remarks.

\section{Empirical methodology and data}

\subsection{Empirical specification}

11. To analyse the determinants of industrial specialisation, this paper adapts the empirical model proposed by Chor (2010) to estimate the determinants of exports. Chor's model incorporates factor endowments and policies as determinants of specialisation in exports. The identification strategy relies on the exogenous differential impact that factor endowments and policies have across different industries, based on the salient role played by a specific factor endowment or policy in each industry's production process. Instead of focusing on gross exports by industry, as Chor (2010), the analysis in this paper uses the value-added share of GDP of each industry as dependent variable. An additional advantage of measuring specialisation using value-added in production is that it is more closely related to trade theory. As explained by Harrigan (1997), the bulk of the intellectual content of trade theory is about production; however, almost all recent empirical works on the determinants of specialisation has used trade data and has not directly measured production.

12. The empirical specification is ${ }^{5}$ :

$$
\text { IndShare }_{\mathrm{ist}}=\alpha+\beta_{1} \text { Endowment }_{\mathrm{it}} * \text { Intensity }_{s}+\beta_{2} \text { Policy }_{\mathrm{it}} * \text { Sensitivity }_{s}+\beta_{3} \text { Tariff }_{\mathrm{sit}}+\Theta_{\mathrm{i}}+\Theta_{\mathrm{st}}+\varepsilon_{\mathrm{ist}}
$$

where $i$ denotes country, $s$ sector (industry) and $t$ year. Endowment is a set of factor endowments at the country level, such as capital per worker and stock of human capital, which varies by country and year. Intensity measures the intensity with which industry $s$ requires the use of the factor endowment. The interaction between Endowment, at the country level, and Intensity, at the industry level, captures the idea that conditions needed for production vary across industries, and countries differ in their ability to provide for these industry-specific requirements. Similarly, Policy denotes the policy and institutional variables, such as financial development, spending in R\&D, regulations, etc., that are measured at the country-level. The policy variable is interacted with Sensitivity, which measures the sensitivity of industry $s$ to the policy. Once again, the approach is based on the idea that due to some salient sectoral characteristics some sectors are inherently more affected than others by certain policies (e.g. Rajan and Zingales 1998).

13. The equation also includes a measure of tariffs. While Kowalski (2011) interacts tariffs with the share of imported intermediate inputs in that industry, to avoid the potential bias due to the fact that the share of imported intermediate inputs may be affected by tariffs, this paper uses a different tariff measure. In this measure (Tariff) the tariffs on good $Z$ is weighted by the importance of that good in the production of industry $s$, as in Bas et al. (2013). ${ }^{6}$ We construct a measure of tariffs at the industry level for each country in the sample and each manufacturing industry as the weighted average of tariffs on the

5 Since the dependent variable is a proxy for production specialisation not trade, the estimation does not include gravity forces as explanatory variables.

6 We also run regressions including, as an additional variable, output tariffs, but the results were not robust and we decided to exclude it. A reason for the lack of robustness, and also a reason not to include output tariffs in the regressions, is that causality is not clear: (1) the share of GDP of industry i could be high because the industry is protected -in which case the sign of the coefficient would be positive; or (2) it could be protected because is a small industry in terms of the share of GDP -in which case the sign of the coefficient would be negative- and the government wants to promote it. 
intermediate goods used in the production of final goods in that industry. For each country $i$, tariffs for the manufacturing sector $s$ and year $t$ are computed as:

$$
\operatorname{Tariff}_{\mathrm{sit}}=\sum_{\mathrm{z}} \alpha_{\mathrm{s}, \mathrm{z}} \tau_{\mathrm{i}, \mathrm{z}, \mathrm{t}}
$$

where $\alpha_{s, z}$ is the share of input $z$ in the production of the final output of sector $\mathrm{s}$ in the United States. The intuition for this index is simple: when the index is high, the goods that industry $s$ uses as main inputs are heavily taxed, thereby increasing production costs and hurting competitiveness in industry $s$. This measure can identify which downstream industries are more affected by the structure of tariffs (not just by the average tariff level). For example, if the production of clothing requires textiles as inputs but production of electronic does not, then tariffs on textiles increase the cost of producing clothing, reducing competitiveness and value added of this industry, but have no effect on the relative cost and competitiveness of the electronic industry. Since higher tariffs on intermediate inputs increase the cost of producing goods in sector $s$ reducing competitiveness and the value added of the industry, the coefficient $\beta_{3}$ should be negative.

14. The regression also includes fixed effects for country $\Theta_{\mathrm{i}}$ and industry-year $\Theta_{\mathrm{st}}$. The country fixed effects capture unobserved country-specific characteristics. The industry-year fixed effects capture unobserved industry characteristics such as how tradable goods are (e.g. the fact that some industries produce goods that are more costly to transport than others) or changes in relative prices among industries that are common in all countries, and time effects that are common to all countries.

\section{$2.2 \quad$ Data}

15. We compiled a pooled cross-country cross-industry and time-series data panel covering 9 emerging and 26 developed countries over the period 1995-2008 (see Table A1 in the appendix for the list of countries). The countries included in the panel cover more than $70 \%$ of world GDP. The panel is unbalanced, with some countries having more observations than others. Tables A1 and A2 in the appendix provide summary statistics of the variables for the full sample. Table A3 in the appendix presents a matrix of correlations among variables in the sample. Data on value added by industry and factor endowments intensities are from the World Input-Output Database (WIOD). ${ }^{7}$ The data distinguishes domestic value added and use of capital and human capital in 26 industries. Data for other explanatory variables are drawn from the World Bank's World Development Indicators, Barro and Lee (2010) and OECD.

16. The dependent variable is a simple specialisation index. Following Harrigan (1995 and 1997) and Redding (2002), we define specialisation as the ratio of industry output over national GDP. Specifically:

$$
\text { IndShare }_{i s t}=\frac{\text { ValueAdded }_{\text {ist }}}{G D P_{i t}}
$$

where IndShare ${ }_{i s t}$ denotes the value added share of industry $s$ in country $i$ 's GDP in period $t$ (both measured in current prices in local currency units).

17. We consider three sets of explanatory variables: (1) measures of factor endowments, including capital per worker and the share of high-skill and low-skill workers in total population, (2) variables that proxy for the level of financial development and the aggregate level of research and development (R\&D) done in each country, and (3) measures of product and labour market regulation, tax structure and tariff structure (see Table A1 in the appendix for summary statistics).

See Timmer et al. (2012) for details on how the database is constructed. 
18. Data on levels of education come from Barro and Lee (2010). High-skilled labour is approximated by the share of the population that has attended at least some tertiary education. Low-skilled labour is the share of the population that has completed, at most, primary education. Medium-skilled labour is the share of the population that has completed or has some secondary education but has never attended tertiary education. Financial development is measured by the $\log$ of the ratio of private domestic credit supplied by private institutions to GDP, and aggregate investment in R\&D is spending in R\&D as percentage of GDP (both variables are from WDI). Labour market regulation is proxied by the OECD indicator of employment protection legislation (EPL) and regulation in product markets by the OECD indicator of anticompetitive regulation in energy, transport and communications (ETCR). Data on labour taxes also come from the OECD databases. We construct the tariff variable using (i) the Most Favourite Nation (MFN) applied tariffs by each of the 37 countries covered in the sample from the WITS/TRAINS/WTO database for the period 1995-2008 and (ii) the input-output tables for the United States sourced from WIOD.

19. Following a standard practice, the industry characteristics are based on data for the US economy (see Table A2 in the appendix for a list of industries used and the respective intensities for each variable) under the assumption that the US economy is the closest to the technological frontier. Although industry characteristics, such as factor intensities, may in principle differ across countries, the empirical strategy would not be invalidated as long as the relative ranking of the industries along each characteristic is similar across countries. ${ }^{8}$

\section{Empirical results}

20. The main results of the paper are reported in Tables 1 to 3 . Table 1 focuses on the effects of factor endowments (capital per worker, high-skill and low-skill workers). Table 2 adds to the regression the proxies for financial development, spending on R\&D and tariffs; and Table 3 incorporates the proxies for product and labour market regulation and tax structure, which are only available for a smaller sample of countries.

\subsection{Factor endowments}

21. The results in Table 1 demonstrate the relevance of Heckscher-Ohlin forces for the cross-country pattern of industrial specialisation. When we interact country measures of endowments per worker with industry measures of factor intensity, the following results emerge:

a) Capital intensive industries thrive in countries where capital is relatively abundant. Capital endowment is measured as the interaction between the country level measure of the capital-labour ratio and the industry intensity in the use of capital. These results suggest that, all else equal, countries with a relatively large capital endowment tend to have a higher share of GDP in industries intensive in the use of capital in production than countries with a relatively lower capital endowment.

b) Countries with high human capital tend to specialise in industries requiring high skills. The country-level measures of human capital (shares of high and low skilled labour) are introduced separately in columns 2 and 3, and then together in column 4. Both measures are interacted with

8 US factor intensities come from WIOD and are defined as the share of each factor in the industries' total purchase (use) of primary factors of production. US industry turnover and job turnover rates come from Bartelsman et al. (2008). US industry dependence on external finance comes from Rajan and Zingales (1998). US R\&D intensity in each industry comes from Criscuolo and Menon (2013). Finally, US industry relative profitability comes from Arnold et al. (2011). 
the intensity with which each industry employs low and high skill workers. The results in Table 1 confirm the relevance of human capital advantage in specialisation patterns: industries intensive in low skill workers take up a larger share of GDP in countries with relatively large endowments of low-skill workers; higher human capital is associated with a higher share of value added of industries intensive in the use of high-skilled workers. Results for both physical and human capital provide support to the predictions of traditional (Hecksher-Ohlin) trade theory.

Table 1. Determinants of industrial specialisation: Factor endowments

Dependent variable: Industry value added as \% of GDP

\begin{tabular}{lcccc}
\hline Variables & $(1)$ & $(2)$ & $(3)$ & $(4)$ \\
\hline Factor Endowments: & & & & \\
Stock of capital per worker * Intensity of capital & $0.1776^{* * *}$ & $0.1713^{* * *}$ & $0.1705^{* * *}$ & $0.1683^{* * *}$ \\
& $(21.106)$ & $(20.358)$ & $(20.068)$ & $(19.839)$ \\
Share of low skill workers* Intensity of low-skill labour & & $0.0888^{* * *}$ & & $0.0550^{* * *}$ \\
& & $(13.958)$ & & $(7.477)$ \\
Share of high skill workers * Intensity of high-skill labour & & & $0.1096^{* * *}$ & $0.0838^{* * *}$ \\
& & & $(9.655)$ & $(6.580)$ \\
Constant & $2.4352^{* * *}$ & $2.1162^{* * *}$ & $1.4933^{* * *}$ & $1.5175^{* * *}$ \\
& $(27.690)$ & $(24.555)$ & $(12.288)$ & $(12.473)$ \\
\hline Country fixed effects & Yes & Yes & Yes & Yes \\
Industry-year fixed effects & Yes & Yes & Yes & Yes \\
Observations & 16,558 & 16,558 & 16,558 & 16,558 \\
R-squared & 0.750 & 0.752 & 0.753 & 0.753 \\
\hline \hline
\end{tabular}

Robust t-statistics in parentheses

$* * * \mathrm{p}<0.01, * * \mathrm{p}<0.05, * \mathrm{p}<0.1$

\subsection{Financial development, $R \& D$ investment and trade policy}

22. Table 2 introduces, one by one, the variables that proxy for the level of financial development, investment in research and development (R\&D) and trade policy. The results provide broad support to the hypothesis that international differences in policies and institutions are associated with different patterns of specialisation across countries.

23. Column 1 introduces the interaction between country-level financial development and industrylevel dependence on external financing (following the methodology of Rajan and Zingales, 1998). With a positive and highly significant coefficient on the interaction term, the results suggest that industries that depend more on external funding represent a higher share of GDP in countries with broader access to credit. A possible explanation is that the financial sector facilitates channelling of savings to the private sector and helps overcome liquidity constraints, thereby enabling the exploitation of economies of scale (e.g. Beck, 2002). Moreover, Rajan and Zingales (1998) emphasized that resource reallocation may be differentially affected by industry characteristics: industries that require substantial upfront external financing (relative to generated cash flow) will be less likely to grow in the presence of capital market imperfections than other industries. Thus, differences in the degree of financial development affect comparative advantage and specialisation towards industries that depend more on external financing.

24. Column 2 introduces the interaction between the country-level total spending on R\&D and a measure of industry propensity to innovate of the industry. When this variable is introduced in the 
regression, the coefficient for high-skilled labour decreases considerably (though remaining strongly significant) suggesting there are complementarities between high skills and $R \& D$ investment. The coefficient for the interaction using $\mathrm{R} \& \mathrm{D}$ spending is positive and significant in all specifications, suggesting that higher spending in $R \& D$ is associated with specialisation in naturally innovative industries. To our knowledge, this is the first study to show that aggregate spending on R\&D affects industrial specialisation. Past studies had emphasized that the production technology was an important determinant of production specialisation (e.g. Harrigan, 1997). More recently, Bournakis et al. (2011) found that, although off-shoring tends to have a negative effect on the value added share of industries such as electrical equipment and business services, the negative effect is compensated by increasing R\&D spending. However, the focus in Bournakis et al. (2011) is different from the one in this paper.

25. Finally, the last column of table 2 reports results for tariffs. The results show that high tariffs are associated with a lower share in GDP of industries that use relatively more intensively the protected intermediate goods in production. The intuition is straightforward: higher tariffs on intermediate inputs increase the cost of production, reducing competitiveness in international markets and, therefore, the potential for industry growth. This result is consistent with studies showing that high tariffs reduce productivity and competitiveness of industries that use relatively more intensively the protected intermediate goods in production (e.g. Bas et al., 2013 and Johansson et al., 2013), but, as far as we know, this is the first study to show that tariffs have a significant negative effect on the share of GDP of downstream industries. 
$\mathrm{ECO} / \mathrm{WKP}(2014) 8$

Table 2. Determinants of industrial specialisation: Factor endowments and policies

Dependent variable: Industry value added as \% of GDP

\begin{tabular}{|c|c|c|c|}
\hline Dependent variable: Industry Value Added as \% of GDP & $(1)$ & (2) & (3) \\
\hline \multicolumn{4}{|l|}{ Factor endowments: } \\
\hline$\overline{\text { Stock of capital per worker * intensity of capital }}$ & $\begin{array}{c}0.1552 * * * \\
(18.515)\end{array}$ & $\begin{array}{c}0.1593 * * * \\
(17.497)\end{array}$ & $\begin{array}{c}0.1612 * * * \\
(16.336)\end{array}$ \\
\hline Share of low skill workers* intensity of Low Skill & $\begin{array}{c}0.0572 * * * \\
(7.791)\end{array}$ & $\begin{array}{c}0.0569 * * * \\
(6.640)\end{array}$ & $\begin{array}{c}0.0657 * * * \\
(6.811)\end{array}$ \\
\hline Share of high skill workers * Intensity of High Skill & $\begin{array}{c}0.0665^{* * * *} \\
(5.325)\end{array}$ & $\begin{array}{c}0.0399 * * * \\
(2.809)\end{array}$ & $\begin{array}{c}0.0392 * * \\
(2.550)\end{array}$ \\
\hline \multicolumn{4}{|l|}{ Policies and institutions: } \\
\hline Financial develpopment $*$ dependance on external finance & $\begin{array}{l}0.1638 * * * \\
(9.933)\end{array}$ & $\begin{array}{c}0.1931 * * * \\
(10.432)\end{array}$ & $\begin{array}{l}0.1885^{* * *} \\
\quad(9.634)\end{array}$ \\
\hline$R \& D$ expenditure * Intensity of $R \& D$ & & $\begin{array}{c}1.2994 * * * \\
(5.143)\end{array}$ & $\begin{array}{c}0.9972 * * * \\
(3.996)\end{array}$ \\
\hline $\begin{array}{l}\text { Tariffs on intermediate inputs } \\
\quad \text { (weighted by share of intermediate in production) }\end{array}$ & & & $\begin{array}{c}-0.0099 * * \\
(-1.997)\end{array}$ \\
\hline Constant & $\begin{array}{l}1.2228 * * * \\
(9.972)\end{array}$ & $\begin{array}{l}1.1424 * * * \\
(8.011)\end{array}$ & $\begin{array}{l}1.2657 * * * \\
(8.284)\end{array}$ \\
\hline Country, industry and year fixed effects & Yes & Yes & Yes \\
\hline Observations & 16,316 & 12,402 & 10,891 \\
\hline R-squared & 0.757 & 0.753 & 0.752 \\
\hline
\end{tabular}

Robust t-statistics in parentheses

$* * * \mathrm{p}<0.01, * * \mathrm{p}<0.05, * \mathrm{p}<0.1$ 


\subsection{Product and labour market regulation and tax structure}

26. Table 3 reports results for policies in product and labour market regulation and taxation. ${ }^{9}$ As data for some of these policies is only available for a smaller sample of countries, results in Table 3 are not comparable with Table 2.

27. Column 1 in Table 3 repeats, for comparison purposes, the last regression of table 2. Column 2 then shows that the coefficient on the interaction between the proxy for labour regulation and job turnover is negative and significant. Thus, stricter EPL is associated with a lower share in GDP of industries with higher job turnover. This is consistent with earlier findings by Cunat and Melitz (2012) highlighting the link between volatility, labour market flexibility, and industrial specialisation in a set-up where differences in labour market regulations affect how firms can adjust to shocks. One explanation is that institutional differences interact with sector specific volatility to affect comparative advantage. Their model predicts that, all else equal, countries with more flexible labour markets tend to specialise in industries with higher volatility, a prediction that is supported also by previous empirical evidence (e.g. Chor 2010; Kowalski 2011).

28. Column 3 introduces the interaction between the proxy for Entry Barriers and a measure of firm turnover. The coefficient for this variable is negative and significant, suggesting that industries with relatively higher turnover produce a lower share of GDP in countries with stricter regulation (although not when all the variables are included together in the regression). This is somewhat consistent with previous studies finding that stringent regulations can disproportionately reduce the efficiency of industries with naturally higher reallocation needs, as measured by firm turnover (e.g. Andrews and Cingano, 2012; Arnold et al., 2011).

29. Finally, columns 4 look at the effect of labour taxes on industrial specialisation. The coefficient for the interaction between the labour tax wedge and the intensity of labour in production is also negative and significant, suggesting that countries with higher labour taxes tend to specialise in industries that are less labour intensive. Indeed, high average labour taxes add to firms' cost of labour, especially when the tax burden cannot be shifted on to lower net wages (e.g. Nickell et al., 2003; Bassanini and Duval, 2006; Murtin et al., 2013), and more so for labour intensive firms or industries.

9. The role of labour market policies has been previously studied by Cunat and Melitz, (2012), Chor (2010) and Kowalski (2011), using a different measure of labour regulation. 
Table 3. Determinants of industrial specialisation: Regulation and Tax Structure

Dependent variable: Indus try Value Added as \% of GDP

Factor Endowments:

Stock of capital per worker * intensity of capital

Share of low skill workers* intensity of low skill

Share of high skill workers * intensity of high skill

Policies and ins titutions:

Financial development $*$ dependence on external finance

$R \& D$ expenditure * intensity of $R \& D$

Trade policy:

Tariffs on intermediate inputs

(weighted by share of intermediate in production)

OECD regulatory variables:

Strictness of employment protection * intensity of job turnover

Entry barries * intensity of industry turnover

Average labor tax wedge * intensity of labor

Constant

Country, industry and year fixed effects

Observations

R-squared

Robust t-statistics in parentheses

*** $\mathrm{p}<0.01, * * \mathrm{p}<0.05,{ }^{*} \mathrm{p}<0.1$
(1)

(2)

(3)

(4)

$\begin{array}{cccc}0.1612 * * * & 0.1671 * * * & 0.1278 * * * & 0.1231 * * * \\ (16.336) & (8.029) & (5.123) & (4.801) \\ 0.0657 * * * & 0.0562 * * * & 0.0578 * * * & 0.0567 * * * \\ (6.811) & (4.886) & (4.423) & (3.928) \\ 0.0392 * * & 0.1301 * * * & 0.1439 * * * & 0.1519 * * * \\ (2.550) & (7.978) & (8.543) & (8.384) \\ & & & \\ 0.1885 * * * & 0.1196 * * * & 0.0974 * * * & 0.1046^{* * *} \\ (9.634) & (5.409) & (4.073) & (4.283) \\ 0.9972 * * * & 1.1069 * * * & 1.1733 * * * & 1.1984 * * * \\ (3.996) & (4.094) & (3.920) & (3.882) \\ & & & \\ -0.0099 * * & -0.0114 * * & -0.0089 * * & -0.0096 * * \\ (-1.997) & (-2.353) & (-1.928) & (-1.952)\end{array}$

\begin{tabular}{lcccc} 
& $(8.284)$ & $(3.567)$ & $(3.941)$ & $(3.578)$ \\
\hline Country, industry and year fixed effects & & & & \\
Observations & Yes & Yes & Yes & Yes \\
R-squared & 10,891 & 8,861 & 7,627 & 6,809 \\
\hline \hline
\end{tabular}

$-0.0235^{* *} \quad-0.0220 * \quad-0.0293 * *$

$\begin{array}{lll}(-2.164) \quad(-1.870) \quad(-2.007) & -0.0019\end{array}$

$-0.0024 * \quad-0.0019$

$(-1.797) \quad(-1.252)$

$-0.0141^{* * *}$

$(-2.708)$

$1.2657 * * * \quad 0.5716^{* * *} \quad 0.7253^{* * *} \quad 0.7318^{* * *}$

$(8.284) \quad(3.567) \quad(3.941) \quad(3.578)$

\subsection{Economic significance of the results}

30. To quantify the economic significance of the link between factor endowments and policies on the one hand and specialisation on the other hand, Figure 4 reports the results of a number of experiments. The goal of the experiments is to measure how much of the cross-country differences in industry share can be explained by cross-country differences in each factor endowment and policy or institution. For example, to measure how differences in the stock of capital can explain differences in the share of GDP of industries intensive in capital, we look at the Electricity, gas and water supply industry, which is around the $90^{\text {th }}$ percentile in the industry distribution in terms of the use of capital (see Table A2 in the appendix). Then, we compare the difference in the share of GDP of that industry between Mexico -a country with relatively low endowment of capital- and Germany -a country with relatively high stock of capital. In 2009, the actual difference was Using the estimated coefficients of Tables 2 and 3 (in each case those resulting from percentage points (see first blue bar in Figure 4). Our empirical model suggests that, because of the 
difference in the stock of capital per capita between Mexico and Germany, the share of the Electricity, gas and water supply industry in Mexico should had been 0.25 percentage points. In other words, the lower stock of capital in Mexico relative to Germany can explain $17 \%$ of the observed difference in the Electricity, gas and water supply industry.

31. For the case of human capital (i.e. the share of high-skilled workers), we compare Spain -a country with an average level of human capital- with Japan -a country at the $75^{\text {th }}$ percentile. In this case, the experiment measures to what extent the differences in human capital between Spain and Japan help explain the differences in the share of GDP of industries with high intensity of human capital $\left(90^{\text {th }}\right.$ percentile of the distribution). The industry at the $90^{\text {th }}$ percentile of dependence in human capital is Electronic goods. In 2009, the share of GDP of the Electronic goods industry was X percentage points higher in Japan than in Spain (Figure 4). The estimates suggest that the share in GDP of the Electronics industry should be 0.5 percentage points higher in Japan than in Spain. Thus, differences in the stock of human capital can explain $23 \%$ of the difference in the share of GDO of the Electronic goods industry between these countries.

32. We also use the Electronic goods industry to quantify the explanatory power of financial development and the Labour tax wedge because the industry is around the $90^{\text {th }}$ percentile in the industry distributions of external financing dependence and intensity of labour (see Table A2). However, for each policy we compare different countries. For example, for financial development we compare Estonia -a country relatively less financially developed- and Sweden -a country with a relatively high Domestic credit over GDP. Here, the estimations suggest that differences in terms of financial development can explain $50 \%$ of the difference in the share of GDP of the Electronic goods industry between Sweden and Estonia ( 0.4 percentage points was the observed difference and 0.2 percentage poi9nts the difference predicted by the model). For labour taxes the explanatory power tends to be smaller (Figure 4). For example, cross-country differences in the average tax wedge between the Netherlands and the United States contribute to explain only 0.05 percentage points of their differences in industrial specialisation of the Electronics goods industry, while the actual difference in 2009 was 0.4 percentage points.

33. For R\&D investment, the estimates suggest that the contribution to GDP of industries that use $\mathrm{R} \& \mathrm{D}$ intensively in its production (e.g. Chemicals), should be 0.18 percentage points higher in Korea, a countries that spends relatively more on $\mathrm{R} \& \mathrm{D}$, than in Slovenia, a country that spends relatively less on R\&D (Figure 4). The actual difference was 1.8 percentage points. Thus, in line with recent evidence highlighting the importance of R\&D to allow resources to flow to innovative sectors (Andrews and Criscuolo, 2013), cross-country differences in R\&D investment could explain as much as $10 \%$ of the differences in the share of GDP of Chemicals and pharmaceuticals industry.

34. Turning to employment and product market regulations, the estimates suggest that a differences in the stringency of product market regulations between United States (a country around the median of the distribution) and Netherlands (a country at the $75^{\text {th }}$ percentile of the distribution) help explain around one tenth of a percentage point of the difference in the value-added share of industries with structurally high turnover, such as Telecommunications, while the actual difference was 0.9 percentage points in 2009 . The quantitative estimates for EPL suggest that differences in labour market regulations between Italy and Denmark, can explain around two tenths of a percentage points of the differences in the value-added share of industries with structurally high job turnover (e.g. Manufacturing nec or Textiles).

35. Finally, we run an experiment to quantitatively estimate how much tariffs affect the share of value added of downstream industries, taking the case of Brazil and tariffs on electronics. The reason for choosing the electronic industry is that it relies heavily on inputs from the same industry ( $45 \%$ of the inputs come from the same industry). Thus, tariffs on foreign electronic goods affect domestic firms that are downstream in the same industry. Brazil was chosen because in the year 2007 it had among the highest 
tariff on electronics (9.51\% weighted average for the industry). The results suggest that the share of GDP of the electronic industry tends to be 0.12 percentage points lower in Brazil than in the European Union which is at the median position of the tariff distribution $(1.1 \%)$ - as a result of the differences in the level of tariffs.

36. In sum, the results on the quantitative impact of factor endowments and policies show that international differences in factor endowments and policies are important determinants of industrial specialisation. As discussed before, although in general policies tend to have lower explanatory power, international differences in policies are, in some cases, as important as factor endowments to explain international differences in industrial specialisation patterns.

\section{Conclusions}

37. Since industrial specialisation is seen as a major force behind economic performance, some commentators argue that governments should use policy to affect specialisation and promote industries that are more likely to increase long run growth and decrease income inequality. This has prompted interest in better understanding the determinants of specialisation placing particular emphasis on the role of policies.

38. A growing literature is analysing how policies and institutions affect industrial specialisation. However, most recent studies focus on a measure of specialisation based on the value of gross exports. This overestimates the importance of some industries in some countries because a large share of gross exports is value added by other countries or by other industries. Moreover, most studies concentrate on manufacturing industries leaving aside services, which is at odds with the important contribution of services to GDP in most countries.

39. This paper re-examined findings by previous studies, and also extended the analysis to include policies not considered before, using a novel database that includes both manufacturing industries and services and allows to measure specialisation in terms of value added. The empirical analysis provided strong evidence that policies and institutions affect industrial specialisation, and that the effect is quantitatively similar to that of factor endowments. The results showed that cross-country differences in capital-to-labour ratios and the shares of low-skilled and high-skilled workers are among the main factors explaining cross-country differences in industrial specialisation patterns. However, cross-country differences in financial development, investment in $\mathrm{R} \& \mathrm{D}$, product and labour market regulation and taxes and tariffs also can also explain why countries specialise in specific industries.

40. Further work needs to be done to establish whether these results are robust to different methodologies, samples of countries and data sources. However, the findings of this study have an important implication for future practice. Very often countries introduce specific policies that target particular industries but forget that other framework policies already in place, and some domestic institutions, are main obstacles for the targeted industry to develop. For example, many countries introduce subsidies or tariffs to support the Electronic goods industry -which is intensive in labour and generates relatively high value added-, while having a relatively low endowment of high-skilled workers, an underdeveloped financial market and a high labour tax wedge. This research suggests that countries should apply a comprehensive approach to design economic policies if they seek to promote specific industries, to avoid inconsistencies between the specific industrial policy and the more general policies and institutional framework already in place. 
Figure 4. Difference in industry share of GDP: actual and explained (predicted) by differences in factor endowments and policies ${ }^{1}$ Difference in share of GDP of industry

at 90th percentile of intensity

(in percentage points)

\section{5} Actual difference in the share of the Electricity, gas and water supply industry Germany

1

0.5

0

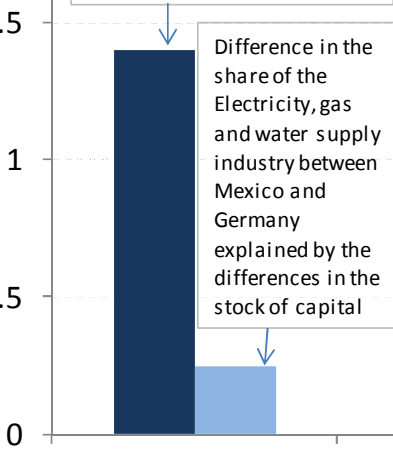

Capital per worker (Mexico vs Germany) Electricity, gas and water supply High-skill workers
(Spain vs Japan)

Electronic goods

Financial development
(Estonia vs Sweden)
Electronic goods

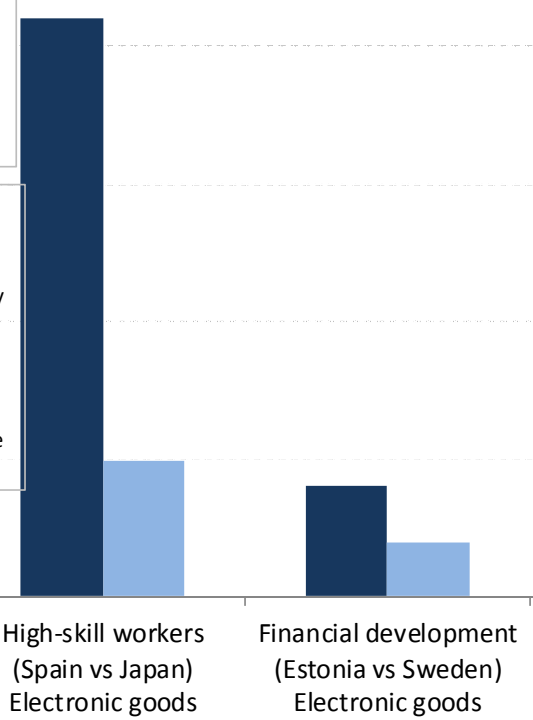

- Actual difference in industry share

Difference in the industry share explained by the difference endowments or policy (predicted)

1. The blue bars show the actual difference (observed in the year 2009) for the in the industry share of the industry considered between the countries considered. The red bars show the predicted difference of the share of GDP between the same countries that is explained by the differences in the factor endowment (policy) being analyzed. The industries considered are those at the $90^{\text {th }}$ percentile level of dependence on the factor endowment (policy). When comparing the country at the median with the country at the $75^{\text {th }}$ percentile of the distribution of the endowment. In the case of EPL, ETRC, Corporate tax and Labour Tax Wedge, the change is from the country at the median to the country at the $25^{\text {th }}$ percentile of the distribution. Tables A1 and A2 in the appendix present a lists of the countries, industries and the corresponding values for each variable. To be specific, the numbers in the figure were estimated with the following formula: $\Delta$ IndShare $=\beta * \Delta E n d * \alpha_{90 t h}$, where $\Delta$ IndShare is the change in the industry share, $\beta$ is the be specific, the numbers in the figure were estimated with the following formula: $\Delta$ IndShare $=\beta * \Delta E n d * \alpha_{90 t h}$, where $\Delta$ IndShare is the change in the industry share, $\beta$ is the
corresponding coefficient from tables 2 and $3, \Delta$ End is the corresponding change in the endowment or policy, and $\alpha_{90 t h}$ is the intensity of the industry at the $90^{\text {th }}$ percentile of the intensity distribution.

Source: OECD estimates. 


\section{BIBLIOGRAPHY}

Aghion, P. and P. Howitt (1998), "Endogenous Growth Theory”, Cambridge, MA, MIT Press.

Amable, B. (2000), "International specialization and growth", Structural Change and Economic Dynamics 11.

Andrews, D. and F. Cingano (2012), "Public Policy and Resource Allocation: Evidence from Firms in OECD countries", OECD Economics Department Working Papers, No. 996, OECD Publishing, Paris.

Andrews, D. and C. Criscuolo (2013), "Knowledge-Based Capital, Innovation and Resource Allocation", OECD Economics Department Working Papers, No. 1046, OECD Publishing, Paris.

Arnold J., Brys, B., Heady, C., Johansson, Å., Schwellnus, C. and L. Vartia, (2011), "Tax Policy for Economic Recovery and Growth", The Economic Journal, Volume 121, Issue 550, pages F59-F80, February.

Barro, R.J. and J.W. Lee (2010), "A New Data Set of Education Attainment in the World, 1950-2010", NBER Working Paper, No. 15902, National Bureau of Economic Research, Inc.

Barro, R.J. and X. Sala-i-Martin (2003), “Economic Growth”, 2nd ed., Cambridge, MA, MIT Press.

Bartelsman, E.J., E. Perotti and S. Scarpetta (2008), "Barriers to Exit, Experimentation and Comparative Advantage", RICAFE2 Working Paper No. 056, London School of Economics.

Bas M., Å. Johansson, F., Murtin and G. Nicoletti (2013), "Do lower tariffs on foreign intermediate inputs raise productivity? Panel data evidence for OECD countries", Mimeo OECD.

Bassanini, A. and R. Duval (2006), "Employment Patterns in OECD Countries: Reassessing the Role of Policies and Institutions, OECD Economics Department Working Papers, No. 486.

Bernstein, J.R. and D.E. Weinstein, (2002), "Do Endowments Predict the Location of Production? Evidence from National and International Data," Journal of International Economics 56:55-76.

Beck, T. (2002), "Financial Development and International Trade. Is There a Link?", Journal of International Economics 57.

Bournakis, I., M. Vecchi and F. Venturini (2011), "Offshoring and specialisation: are industries moving abroad?", Quaderndi di Dipartimento, DEFS, University of Perugia.

Chor, D. (2010), "Unpacking Sources of Comparative Advantage: A Quantitative Approach", Journal of International Economics, Vol. 82 (2010) 152-167.

Criscuolo, C. and C. Menon (2013), "Feeding Green Ideas: Risk Finance in the Cleantech Sector", forthcoming DSTI Working Paper, OECD Publishing, Paris 
Cunat, A. and M. J. Melitz (2012), "Volatility, Labor Market Flexibility, and the Pattern of Comparative Advantage", Journal of the European Economic Association 10: 225-254.

Dalum, B., K. Laursen and B. Verspagen (1999), “Does specialization matter for growth?”, Industrial and Corporate Change, Vol. 8, Oxford University Press.

Davis, D.R. and D. E. Weinstein (1999), "Economic Geography and Regional Production Structure: an Empirical Investigation," European Economic Review 43:379-407.

Grossman, G.M. and E. Helpman (1991), "Quality Ladders in the Theory of Growth," The Review of Economic Studies, Vol. 58: 43-61.

Harrigan, J. (1995). "Factor Endowments and the International Location of Production: Econometric Evidence for the OECD, 1970-1985," Journal of International Economics 39: 123-41.

Harrigan, J. (1997). "Technology, Factor Supplies, and International Specialization: Estimating the Neoclassical Model," American Economic Review 87:475-94.

Harrigan, J. (1999), "Estimation of Cross-country Differences in Industry Production Functions," Journal of International Economics 47.

Harrigan, J. and E. Zakrajsek (2000), "Factor Supplies and Specialization in the World Economy," Finance and Economics Discussion Series 2000-43, Federal Reserve Board of Governors.

Haskel J., R.Z. Lawrence and E. Leamer (2012), "Globalization and U.S. Wages: Modifying Classic Theory to Explain Recent Facts", Journal of Economic Perspectives, Vol. 26.

Hausmann, R, J. Hwang and D. Rodrik (2007), "What You Export Matters", Journal of Economic Growth, Vol.12:1-25.

Heckscher, E.F. and B, Ohlin (1991), "Heckscher-Ohlin Trade Theory”, Cambridge, MA, MIT Press.

Johansson, Å, P. Kowalski, E. Olaberría and D. Pallergirno (2013), "What explains the volume and composition of trade: Industrial evidence from a panel of countries", OECD Working Paper, forthcoming, OECD Paris.

Koopman, R., W. Powers, Z. Wang and S.J. Wei (2010), "Give Credit Where Credit Is Due: Tracing Value Added in Global Production Chains", NBER Working Papers No. 16426, National Bureau of Economic Research, Inc.

Kowalski, P. (2011), "Comparative Advantage and Trade Performance: Policy Implications", OECD Trade Policy Working Papers, No 925, OECD Publishing, Paris.

Matsuyama, K. (1992), “Agricultural Productivity, Comparative Advantage, and Economic Growth", Journal of Economic Theory, December.

Miroudot, S., R. Lanz and A. Ragoussis (2009), "Trade in Intermediate Goods and Services", OECD Trade Policy Working Papers, No. 93, OECD Publishing, Paris

Murtin, F., A. de Serres, and A. Hijzen (2013), "The Ins and Outs of Unemployment: The role of Labour Market Institutions", OECD Economics Department Working Paper, forthcoming, OECD Publishing, Paris. 
Nickell, S.J., L. Nunziata, W. Ochel and G. Quintini (2003), "The Beveridge Curve, Unemployment and Wages in the OECD from the 1960s to the 1990s", in P. Aghion, R. Frydman, J. Stiglitz and M. Woodford (eds.), Knowledge, Information and Expectations in Modern Macroeconomics: In Honor of Edmund S. Phelps, (Princeton: Princeton University Press).

Nunn, N. and D. Trefler (2013), "Domestic Institutions as a Source of Comparative Advantage", NBER Working Papers, No. 18851, National Bureau of Economic Research, Inc.

OECD (2009), Going for Growth, Economic Policy Reforms 2010, Chapter 5, OECD Publishing, Paris.

Rajan, R.G. and L. Zingales (1998), "Financial dependence and growth", American Economic Review, Vol. 88, 559-586.

Redding, S. (2002), “Specialization dynamics”, Journal of International Economics 58 299-334

Reeve, T. (1998), “Explaining Industrial Structure,” Harvard University, mimeo.

Timmer, M. P., B. Los, R. Stehrer and G. de Vries (2012). "Fragmentation, Incomes and Jobs. An analysis of European competitiveness", Working Paper No. 9, WIOD. 
ECO/WKP(2014)8

\section{APPENDIX}

Table A1. List of countries and summary statistics for the variables

\begin{tabular}{|c|c|c|c|c|c|c|c|c|}
\hline Country & $\begin{array}{c}\text { Capital per } \\
\text { worker }\end{array}$ & $\begin{array}{l}\text { Share of low- } \\
\text { skill workers }\end{array}$ & $\begin{array}{l}\text { Share of high- } \\
\text { skill workers }\end{array}$ & $\begin{array}{c}\text { Financial } \\
\text { development }\end{array}$ & $\begin{array}{c}\text { R\&D } \\
\text { expenditure }\end{array}$ & EPL & $\begin{array}{c}\text { Entry } \\
\text { Barriers }\end{array}$ & $\begin{array}{c}\text { Labour } \\
\text { taxes }\end{array}$ \\
\hline (1) Australia & 9.08 & 3.68 & 34.52 & 4.96 & 2.26 & 1.15 & 0.60 & 27.7 \\
\hline (2) Austria & 9.30 & 24.61 & 12.36 & 4.87 & 2.52 & 1.93 & 1.10 & 48.8 \\
\hline (3) Belgium & 9.23 & 21.41 & 23.99 & 4.73 & 1.90 & 2.18 & 1.30 & 55.6 \\
\hline (4) Brazil & 7.54 & 48.03 & 7.41 & 4.57 & 1.07 & $\mathrm{n} / \mathrm{a}$ & 2.20 & $\mathrm{n} / \mathrm{a}$ \\
\hline (5) Canada & 8.99 & 5.89 & 35.19 & 5.18 & 1.91 & 0.75 & 1.30 & 31.2 \\
\hline (6) Chile & 7.89 & 25.24 & 26.92 & 4.45 & 0.33 & $\mathrm{n} / \mathrm{a}$ & 1.40 & 7.0 \\
\hline (7) China & 6.96 & 30.60 & 9.05 & 4.79 & 1.40 & $\mathrm{n} / \mathrm{a}$ & 4.60 & $\mathrm{n} / \mathrm{a}$ \\
\hline (8) Czech Republic & 8.53 & 13.84 & 10.65 & 4.02 & 1.54 & 1.96 & 0.50 & 42.9 \\
\hline (9) Denmark & 9.30 & 40.99 & 20.86 & 5.34 & 2.58 & 1.50 & 0.30 & 41.1 \\
\hline (10) Estonia & 8.29 & 6.09 & 26.84 & 4.56 & 1.11 & $\mathrm{n} / \mathrm{a}$ & 2.30 & 39.0 \\
\hline (11) Finland & 9.28 & 32.83 & 24.50 & 4.48 & 3.47 & 2.02 & 1.30 & 43.9 \\
\hline (12) France & 9.23 & 16.02 & 20.28 & 4.82 & 2.08 & 3.05 & 1.30 & 49.7 \\
\hline (13) Germany & 9.29 & 10.43 & 17.81 & 4.84 & 2.53 & 2.12 & 0.40 & 51.9 \\
\hline (14) Greece & 8.87 & 28.62 & 23.90 & 4.75 & 0.58 & 2.73 & 1.20 & 41.8 \\
\hline (15) Hungary & 8.56 & 5.95 & 15.89 & 4.39 & 0.97 & 1.65 & 1.60 & 54.5 \\
\hline (16) India & 6.53 & 53.59 & 5.76 & 4.21 & 0.76 & $\mathrm{n} / \mathrm{a}$ & 2.10 & $\mathrm{n} / \mathrm{a}$ \\
\hline (17) Indonesia & 6.72 & 69.91 & 2.48 & 3.60 & 0.07 & $\mathrm{n} / \mathrm{a}$ & 3.00 & $\mathrm{n} / \mathrm{a}$ \\
\hline (18) Ireland & 9.27 & 16.53 & 30.74 & 5.33 & 1.29 & 1.11 & 1.70 & 22.2 \\
\hline (19) Italy & 9.22 & 23.88 & 10.18 & 4.88 & 1.18 & 1.82 & 1.40 & 46.4 \\
\hline (20) Japan & 9.33 & 16.97 & 37.33 & 5.71 & 3.44 & 1.43 & 1.80 & 29.3 \\
\hline (21) Korea & 8.72 & 13.06 & 40.14 & 4.69 & 3.21 & 2.03 & 2.90 & 19.7 \\
\hline (22) Luxembourg & 9.76 & 28.59 & 15.21 & 5.21 & 1.58 & $\mathrm{n} / \mathrm{a}$ & 1.00 & 36.3 \\
\hline (23) Mexico & 8.20 & 31.67 & 16.70 & 3.62 & 0.37 & 3.13 & 3.60 & 15.9 \\
\hline (24) Netherlands & 9.19 & 12.49 & 23.02 & 5.28 & 1.81 & 2.04 & 1.30 & 38.7 \\
\hline (25) New Zealand & 8.83 & 24.29 & 51.49 & 5.03 & 1.17 & 1.47 & 1.00 & 21.1 \\
\hline (26) Norway & 9.56 & 2.97 & 25.58 & 4.47 & 1.65 & 2.69 & 1.60 & 37.5 \\
\hline (27) Poland & 8.12 & 21.90 & 15.27 & 4.09 & 0.57 & 1.90 & 1.20 & 38.2 \\
\hline (28) Portugal & 8.66 & 54.65 & 10.82 & 5.18 & 1.17 & 3.46 & 1.30 & 37.3 \\
\hline (29) Russia & 7.43 & 6.72 & 55.97 & 3.18 & 1.12 & $\mathrm{n} / \mathrm{a}$ & 1.60 & $\mathrm{n} / \mathrm{a}$ \\
\hline (30) Slovak Republic & 8.24 & 18.81 & 12.57 & 3.99 & 0.46 & 1.34 & 0.90 & 38.4 \\
\hline (31) Slovenia & 8.78 & 4.54 & 17.04 & 4.47 & 1.45 & $\mathrm{n} / \mathrm{a}$ & 1.70 & 43.3 \\
\hline (32) Spain & 9.00 & 24.80 & 24.06 & 5.37 & 1.27 & 2.98 & 1.10 & 39.0 \\
\hline (33) Sweden & 9.28 & 10.65 & 23.64 & 4.98 & 3.40 & 2.24 & 0.50 & 45.3 \\
\hline (34) Switzerland & 9.40 & 35.55 & 17.45 & 5.20 & 2.97 & 1.14 & 1.70 & 21.9 \\
\hline (35) Turkey & 8.07 & 52.81 & 9.30 & 3.96 & 0.72 & 3.72 & 2.40 & 42.7 \\
\hline (36) United Kingdom & 9.09 & 27.42 & 23.97 & 5.36 & 1.78 & 0.75 & 0.90 & 34.1 \\
\hline (37) United States & 9.10 & 2.77 & 51.81 & 5.40 & 2.67 & 0.21 & 1.70 & 30.3 \\
\hline Median & 8.20 & 21.90 & 24.06 & 4.56 & 1.45 & 1.82 & 1.60 & 38.7 \\
\hline 75th percentile & 9.29 & 30.60 & 37.33 & 4.98 & 3.21 & 1.50 & 1.30 & 30.3 \\
\hline
\end{tabular}

Notes: Data is for the last year for which we have data. Capital per worker the year is 2008; for human capital is 2010; Financial Development is 2009 (Norway 2006); R\&D 2009; EPL, Entry Barriers and Labour Taxes is 2007 
Table A2. List of industries and intensities

\begin{tabular}{|c|c|c|c|c|c|c|c|c|c|}
\hline Industry/Sector & $\begin{array}{c}\text { Intensity of } \\
\text { Capital }\end{array}$ & $\begin{array}{l}\text { Intensity Low- } \\
\text { skill workers }\end{array}$ & $\begin{array}{l}\text { Intensity High- } \\
\text { skill workers }\end{array}$ & $\begin{array}{l}\text { Dependance of } \\
\text { External Finance }\end{array}$ & $R \& D$ Intensity & $\begin{array}{l}\text { Intensity of Firm } \\
\text { Turnover }\end{array}$ & $\begin{array}{l}\text { Intensity of Job } \\
\text { Turnover }\end{array}$ & $\begin{array}{l}\text { Industry Relative } \\
\text { Profitability }\end{array}$ & $\begin{array}{l}\text { Labour } \\
\text { intensity }\end{array}$ \\
\hline (1) Basic metals & 0.15 & 0.14 & 0.15 & 0.44 & 0.01 & 14.6 & 35.5 & 0.52 & 0.68 \\
\hline (2) Construction & 0.11 & 0.21 & 0.11 & 0.19 & 0.00 & 22.6 & 58.6 & 0.33 & 0.66 \\
\hline (3) Chemicals and chemical & 0.35 & 0.05 & 0.45 & 6.20 & 0.13 & 14.7 & 30.4 & 1.60 & 0.45 \\
\hline (4) Coke, refined petroleum and nuclear fuel & 0.63 & 0.07 & 0.32 & 0.78 & 0.05 & 16.2 & 40.1 & 1.42 & 0.23 \\
\hline (5) Electronic goods & 0.28 & 0.06 & 0.43 & 1.62 & 0.27 & 23.6 & 37.0 & 0.57 & 0.80 \\
\hline (6) Electricity, gas and water supply & 1.31 & 0.04 & 0.28 & 0.12 & 0.00 & 7.3 & 18.3 & $\mathrm{n} / \mathrm{a}$ & 0.27 \\
\hline (7) Financial intermediation & 0.30 & 0.01 & 0.45 & 1.60 & 0.00 & 21.5 & 42.2 & $\mathrm{n} / \mathrm{a}$ & 0.53 \\
\hline (9) Leather, leather and footwear & 0.11 & 0.28 & 0.14 & 0.19 & 0.01 & 26.4 & 45.6 & 0.75 & 0.80 \\
\hline (10) Machinery nec & 0.27 & 0.08 & 0.24 & 0.19 & 0.06 & 14.4 & 33.6 & 0.82 & 0.71 \\
\hline (11) Manufacturing nec & 0.12 & 0.18 & 0.18 & 0.17 & $\mathrm{n} / \mathrm{a}$ & 20.4 & 43.5 & 0.83 & 0.65 \\
\hline (12) Other non-metalic minerals & 0.22 & 0.14 & 0.17 & 0.00 & 0.02 & 15.0 & 38.7 & 1.15 & 0.59 \\
\hline (13) Other Air transport & 0.86 & 0.12 & 0.15 & 0.43 & 0.00 & 24.0 & 42.6 & 0.70 & 0.70 \\
\hline (14) Other Inland transport & 0.30 & 0.12 & 0.15 & 0.43 & 0.00 & 24.0 & 42.6 & 0.70 & 0.63 \\
\hline (15) Other Water transport & 1.36 & 0.12 & 0.15 & 0.43 & 0.00 & 24.0 & 42.6 & 0.70 & 0.46 \\
\hline (16) Telecomunications & 0.66 & 0.02 & 0.28 & 1.67 & 0.00 & 24.0 & 31.3 & 1.19 & 0.50 \\
\hline (17) Paper and printing & 0.16 & 0.08 & 0.31 & 0.09 & 0.01 & 17.8 & 36.6 & 1.09 & 0.66 \\
\hline (19) Renting of m\&eq and other business activities & 2.79 & 0.09 & 0.45 & 3.35 & 0.00 & 21.5 & 48.5 & 1.37 & 0.17 \\
\hline (20) Retail trade, except of motor vehicles & 0.16 & 0.12 & 0.20 & 0.75 & 0.02 & 21.8 & $\mathrm{n} / \mathrm{a}$ & 0.58 & 0.56 \\
\hline (21) Rubber and plastics & 0.23 & 0.14 & 0.16 & 0.56 & 0.03 & 16.5 & 35.8 & 1.00 & 0.61 \\
\hline (22) Sale, maintenance and repair of motor vehicles & 0.16 & 0.08 & 0.28 & 0.75 & 0.02 & 21.8 & $\mathrm{n} / \mathrm{a}$ & 0.58 & 0.56 \\
\hline (23) Transport equipment & 0.22 & 0.08 & 0.26 & 0.20 & 0.18 & 16.5 & 30.3 & 0.67 & 0.70 \\
\hline (24) Textiles and textile & 0.12 & 0.28 & 0.14 & 0.19 & 0.01 & 26.4 & 45.6 & 0.75 & 0.73 \\
\hline (25) Wood products & 0.14 & 0.19 & 0.11 & 0.01 & 0.00 & 20.8 & 43.7 & 0.66 & 0.75 \\
\hline (26) Wholesale trade and commission trade & 0.16 & 0.11 & 0.13 & 0.75 & 0.02 & 21.8 & $\mathrm{n} / \mathrm{a}$ & 0.58 & 0.56 \\
\hline 10th percentile industry & 0.12 & 0.05 & 0.13 & 0.11 & 0.00 & 14.65 & 30.61 & 0.57 & 0.25 \\
\hline 90th percentile industry & 1.34 & 0.20 & 0.44 & 2.51 & 0.10 & 24.00 & 47.89 & 1.36 & 0.74 \\
\hline
\end{tabular}


Table A3. Pairwise correlations between the dependant and explanatory variables

\begin{tabular}{|c|c|c|c|c|c|c|c|c|c|c|c|}
\hline Variables & (1) & (2) & (3) & (4) & (5) & (6) & (7) & (8) & (9) & $(10)$ & (11) \\
\hline (1) Industry Share & 1.00 & & & & & & & & & & \\
\hline (2) Stock of capital per worker * intensity of capital & 0.51 & 1.00 & & & & & & & & & \\
\hline (3) Share of low skill workers* intensity of Low Skill & -0.12 & -0.18 & 1.00 & & & & & & & & \\
\hline (4) Share of high skill workers * Intensity of High Skill & 0.22 & 0.23 & -0.53 & 1.00 & & & & & & & \\
\hline (5) Financial develpopment * dependance on external finance & 0.32 & 0.43 & -0.31 & 0.44 & 1.00 & & & & & & \\
\hline (6) R\&D expenditure * Intensity of R\&D & -0.11 & -0.12 & -0.18 & 0.34 & 0.24 & 1.00 & & & & & \\
\hline (7) Tariffs on intermediate inputs & -0.15 & -0.21 & 0.38 & -0.24 & -0.16 & -0.02 & 1.00 & & & & \\
\hline (8) Average Labor Tax wedge * intensity of labor & -0.36 & -0.47 & 0.18 & -0.41 & -0.35 & 0.14 & 0.07 & 1.00 & & & \\
\hline (9) ETCR Overall * Intensity of Industry Turnover & 0.02 & 0.01 & 0.49 & -0.44 & -0.05 & -0.13 & 0.16 & 0.13 & 1.00 & & \\
\hline (10) Strictness of Employ Regulation Overall * Intensity of Job Turnover & -0.12 & -0.17 & 0.54 & -0.39 & -0.13 & 0.01 & 0.24 & 0.33 & 0.51 & 1.00 & \\
\hline (11) Combined corporate income tax rate * Industry relative profitability & -0.06 & 0.31 & -0.04 & 0.20 & 0.45 & 0.03 & 0.01 & -0.25 & 0.11 & 0.00 & 1.00 \\
\hline
\end{tabular}




\section{WORKING PAPERS}

The full series of Economics Department Working Papers can be consulted at www.oecd.org/eco/workingpapers/

1111. Economic growth from the household perspective: GDP and income distribution developments across OECD countries

(April 2014) by Orsetta Causa, Sonia Araujo, Agnès Cavaciuti, Nicolas Ruiz and Zuzana Smidova

1110. Would a growth slowdown in emerging markets spill over to high-income countries? A quantitative assessment (April 2014) By Patrice Ollivaud, Elena Rusticelli and Cyrille Schwellnus

1109. Short-term indicator models for quarterly GDP growth in the BRIICS: A small-scale bridge model approach

(April 2014) by Thomas Chalaux and Cyrille Schwellnus

1108. The prudential regulation of financial institutions: why regulatory responses to the crisis might not prove sufficient

(March 2014) by William R. White

1107. OECD forecasts during and after the financial crisis: a post mortem

(March 2014) by Nigel Pain, Christine Lewis, Thai-Thanh Dang, Yosuke Jin and Pete Richardson

1106. Fairly sharing the social impact of the crisis in Greece

(January 2014) by Vassiliki Koutsogeorgopoulou, Manos Matsaganis, Chrysa Leventi and Jan-David Schneider

1105. Dividing the pie in Brazil: income distribution, social policies and the new middle class

(January 2014) by Jens M. Arnold and João Jalles

1104. New indicators of competition law and policy in 2013 for OECD and non-OECD countries (December 2013) by Enrico Alemani, Caroline Klein, Isabell Koske, Cristiana Vitale and Isabelle Wanner

1103. The effect of government debt, external debt and their interaction on OECD interest rates (December 2013) by David Turner and Francesca Spinelli

1102. The state of the banking sector in Europe

(December 2013) by Dirk Schoenmaker and Toon Peek

1101. Getting Irish youth on the job track

(December 2013) by Alberto González Pandiella

1100. New econometric estimates of long-term growth effects of different areas of public spending (December 2013) by Omar Barbiero and Boris Cournède

1099. Cross-country spillovers from fiscal consolidations

(December 2013) by Antoine Goujard 
1098. Informal employment in Russia: definitions, incidence, determinants and labour market segmentation

(December 2013) by Hartmut Lehmann and Anzelika Zaiceva

1097. Capacity needs in the automobile industry in the short- to medium run

(November 2013) by Caroline Klein and Isabell Koske

1096. Environmental policies and productivity growth - a critical review of empirical findings

(November 2013) by Tomasz Koźluk and Vera Zipperer

1095. Green growth challenges and the need for an energy reform in Mexico

(November 2013) by Carla Valdivia de Richter

1094. From bricks to brains: increasing the contribution of knowledge-based capital to growth in Ireland

(November 2013) by David Haugh

1093. China's march to prosperity: reforms to avoid the middle-income trap

(November 2013) by Vincent Koen, Richard Herd and Sam Hill

1092. Multi factor productivity with natural capital

(November 2013) by Nicola Brandt, Paul Schreyer and Vera Zipperer

1091. Growth-promoting policies and macroeconomic stability

(November 2013) by Douglas Sutherland and Peter Hoeller

1090. Policies for inclusive urbanisation in China

(October 2013) by Vincent Koen, Richard Herd, Xiao Wang and Thomas Chalaux

1089. Fiscal devaluation - can it help to boost competitiveness?

(October 2013) by Isabell Koske

1088. How to achieve growth- and equity-friendly fiscal consolidation? A proposed methodology for instrument choice with an illustrative application to OECD countries

(October 2013) by Boris Cournède, Antoine Goujard and Álvaro Pina

1087. Improving school-to-work transition in New Zealand

(September 2013) by Alexandra Bibbee

1086. The agri-food situation and policies in Switzerland

(September 2013) by Peter Jarrett and Charlotte Moeser

1085. Japan's challenging debt dynamics

(August 2013) by Yvan Guillemette and Jan Strasky

1084. Transitions in and out of unemployment among young people in the Irish recession

(August 2013) by Elish Kelly, Seamus McGuinness, Philip O'Connell, David Haugh and Alberto González Pandiella

1083. Is there convergence of Russia's regions? Exploring the empirical evidence: 1995-2010

(August 2013) Hartmut Lehmann and Maria Giulia Silvagni 